\title{
A Study of Optimum Formula for Healthy Thai Jelly Sugar Candy Production
}

\section{Narin CHAROENPHUN}

Faculty of Agricultural Technology, Burapha University Sakaeo Campus, Sakaeo 27160, Thailand

(Corresponding author's e-mail: narinch@buu.ac.th)

Received: 14 March 2020, Revised: 25 April 2021, Accepted: 30 April 2021

\begin{abstract}
This research developed healthy Thai jelly sugar candy (TJSC) products with a mixture design. Physical properties and sensory acceptance by untrained panelists were investigated. The results showed that the suitable ratio of coconut milk, sugar, and wheat flour were 60,30 , and $10 \%$, respectively. The effect of different flour replacing wheat flour on the quality of TJSC was examined. It was found that TJSC produced from non-glutinous rice flour had the most physical properties like wheat flour, and the overall liking score was not different from wheat flour $(p>0.05)$. The optimum ratio of corn milk instead of coconut milk was investigated. The ratio of corn milk per coconut milk was 50:50 had a high overall liking score, and it was not different from the formula with $100 \%$ of coconut milk. The stevia instead some parts of sugar were explored. It was found that the optimum ratio of sugar to stevia leaf extract was 80:20, which was a formula with an overall liking score not different from $100 \%$ of sugar. The chemical composition of healthy TJSC products was analyzed. It has a lower total amount of fat and energy than the control formula. In addition, the development of flavoring with herbs such as ginger, galangal, lemongrass, and sunchoke made diverse products. Therefore, healthy TJSC products can be used as an alternative food for consumers who have limited intake.
\end{abstract}

Keywords: Corn milk, Non-glutinous rice flour, Stevia leaf extract, Thai jelly sugar candy

\section{Introduction}

TJSC (kanom Ar Lua) is a sweet dessert that looks like a sharp peak. These are crispy outer surfaces, soft inside like a quince rubber, the colors and flavors are added. Generally, the main components of TJSC are coconut milk, sugar, and wheat flour. TJSC production, the ingredients are mixed and stirred under heating after that forming into small pieces, and then is dried by the sun or hot air oven. It is a sweet dessert that has a long shelf life. Specifically, TJSC contains $50-60 \%$ sugar [1]. It is a dessert that has a high amount of sugar and fat from coconut milk. For this reason, it is a limitation for eating of certain consumer groups such as diabetic patients, high blood pressure, obesity, and weight control, etc. Furthermore, TJSC also contains wheat flour, so that consumers who are allergic to the gluten protein in wheat flour cannot eat it. The development of health food products for consumers who have dietary restrictions is focused. It is an interesting choice and an alternative product for healthconscious consumers.

At present, there are many research reports for using other flour to replace wheat flour in gluten-free food such as rice flour [2] tapioca flour [3] corn flour and bean flour [4], etc. Each flour has different physicochemical properties which may affect the quality of food products. In general, wheat flour is used to produce TJSC contains gluten protein. It causes the toughness and flexibility of the product that has a good appearance and texture. Using other flour instead of wheat flour may deteriorate the quality of the product. There was a report on the use of tapioca flour instead of wheat flour in cookie products. It was found that the hardness of the cookies tended to increase when the amount of tapioca flour increased [5]. 
http://wjst.wu.ac.th

Selecting the right flour to replace wheat flour for making TJSC products that the same quality as wheat flour is necessary. Moreover, coconut milk is an important ingredient for TJSC production. It is the liquid extracted from the flesh of a mature coconut. Fat is the main element in coconut milk that is an emulsion form. Specifically, coconut milk is popular in Thai food because of its fragrant aroma, sweetness, oiliness, and the usefulness as food ingredient [6]. Reducing the fat content in TJSC may use other raw materials instead of using some coconut milk such as soy milk [7] corn milk [8] milk [9] or cereal milk which is sold in the form of instant coconut milk. Interestingly, corn milk is a raw material that is readily available locally. Its distinctive feature is its fragrant aroma and sweet taste. It is rich in nutrition, and it is a good source of vitamin A, vitamin B, vitamin C, and niacin. Besides, there are saturated fats and low cholesterol food [10]. Therefore, corn milk is a raw material that has been selected to replace some coconut milk in the development of healthy TJSC products in this study. In terms of sweetness, TJSC has a high sugar content. Using some sugar substitutes to produce TJSC can help reduce sugar consumption. Alternatively, stevia leaf extract (Stevia Rebaudiana Bertoni) is an interesting option. Because it is a sweetener that does not give energy or provides low energy. It is suitable for control weight consumers and diabetic patients. It is safe for consumption. Thus, it is allowed to use as a sugar substitute in many countries and is likely to be used as a raw material in food production continuously [11]. The color, fragrance, and taste of TJSC products which are sold in general will have a natural appearance of raw materials. In the trade, artificial colors and fragrances are used in production, or baking by a smoke candle for a fragrant aroma. The use of local herbs as raw materials to the flavor of TJSC may be another way for consumers who are health conscious. In addition, the benefits of herbs for health is found, and also help to increase the variety of products that consumers have more options to eat.

Highlights of this research: increasing dietary choices for gluten intolerance, avoiding high-sugar and high-fat diet consumers. Moreover, it promotes the use of Thai herbs in food. The objective of this research is to study the optimum formula for producing TJSC, and the development of healthy TJSC products. Using various types of flour substitute to replace wheat flour, the effect of corn milk as a substitute for some coconut milk, the use of stevia leaf extracted to replace sugar, and the enhancement of local herbs on the quality of TJSC was studied. Evaluating the physicochemical properties and sensory acceptance of consumers to select the prototype formula for healthy TJSC products were investigated. Knowledge from this research can be further developed into commercial production in the future.

\section{Materials and methods}

\section{Study of the effects of coconut milk, sugar, and wheat flour on the quality of TJSC}

Experimenting to find the appropriate ratio for TJSC production was studied. The thirteen formulas of TJSC consisting of coconut milk (50-70\%), sugar $(20-40 \%)$, and wheat flour $(0-20 \%)$ were studied using Mixture Design. The production of the TJSC method was modified from Srisangwan [1]. Coconut milk, sugar, and wheat flour were weighed according to the formulas in Table 1. In terms of TJSC production, wheat flour was sifted. Next, sugar and coconut milks were added and mixed. The mixture was stirred in the pot by using medium heat for $15 \mathrm{~min}$. After heat, it was cool at room temperature and form. After all, it was baked at $60^{\circ} \mathrm{C}$ for $10 \mathrm{~h}$.

Table 1 Formulation of TJSC by a 3-component* mixture design.

\begin{tabular}{llllllllllllll}
\hline \multirow{2}{*}{ Ingredients } & \multicolumn{10}{c}{ Formulation } \\
\cline { 2 - 12 } & $\mathbf{1}$ & $\mathbf{2}$ & $\mathbf{3}$ & $\mathbf{4}$ & $\mathbf{5}$ & $\mathbf{6}$ & $\mathbf{7}$ & $\mathbf{8}$ & $\mathbf{9}$ & $\mathbf{1 0}$ & $\mathbf{1 1}$ & $\mathbf{1 2}$ & $\mathbf{1 3}$ \\
\hline Coconut milk (\%) & 60 & 65 & 60 & 50 & 60 & 55 & 65 & 50 & 60 & 60 & 70 & 70 & 55 \\
Sugar (\%) & 25 & 25 & 30 & 40 & 35 & 30 & 30 & 30 & 40 & 20 & 20 & 30 & 35 \\
Wheat flour (\%) & 15 & 10 & 10 & 10 & 5 & 15 & 5 & 20 & 0 & 20 & 10 & 0 & 10 \\
Total & 100 & 100 & 100 & 100 & 100 & 100 & 100 & 100 & 100 & 100 & 100 & 100 & 100 \\
\hline
\end{tabular}

*A 3-component mixture (100\% in the mixture design) was $100 \%$ of the total formulation. 
http://wjst.wu.ac.th

All thirteen formulas of TJSC were observed. The total soluble solid content of TJSC was measured with a hand refractometer (ATAGO MASTER-M, China). The viscosity of TJSC before forming was investigated with a viscosity meter (CSC scientific Bostwick consistometer, 24925-000, USA). The pies before baking and after baking were weighed by balance (Zepper EPS-3001, China). The baking loss was defined as follows: baking loss $(\%)=[$ (Weigh of TJSC before baking- Weigh of TJSC after baking)/ Weigh of TJSC before baking] $\times 100$ [12]. Hardness was investigated by texture instrument (Daiichi FG $520 \mathrm{~K}$, Japan). The unit of force was newton (N). The color of TJSC was investigated by the color meter (Colorimeter, WR10QC, China). The CIE system was defined by L * or brightness $(0=$ black, $100=$ white $), a *(+a=$ red, $-a=$ green $)$ and $b *(+b=$ yellow, $-b=$ Blue $)$. Furthermore, sensory evaluation by 30 untrained panelists was investigated. They were between 20 - 50 years old, who had never eaten TJSC. Moreover, they were not foods allergic that contained TJSC ingredients. This work has been already considered the ethics in research with humans for sensory analysis (Sci 088/2562). The importance of liking of appearance, flavor, texture, taste, and overall liking was expressed by a 9-point hedonic scale. A suitable formula was selected for developing TJSC products. The contour plot was overlapped to find the right ratio of the amount of coconut milk, sugar, and wheat flour. The quality of TJSC composes of total soluble solids, viscosity, weight loss, hardness, color, and sensory evaluation scores were used for selecting the appropriate formula of TJSC. TJSC

Study of the effect of different types of flour in substitution of wheat flour on the quality of

Durian rind flour was prepared from unripe Monthong durian (Durio zibethinus murray). It was separated from the flesh and seed of durian. The part of the edible durian rind was selected and cut into small pieces. It was dried in a hot air oven at $60{ }^{\circ} \mathrm{C}$ for $18 \mathrm{~h}$. In addition, the flesh of purple sweet potato (Ipomoea batatas (L.) Lam.), pisang awak (Musa (ABB group)), and pumpkin (Cucurbita moschata Decne.) were selected. It was peeled and cut into small pieces. It was dried in a hot air oven at $60{ }^{\circ} \mathrm{C}$ for $18 \mathrm{~h}$. Dried durian rind, purple sweet potato, banana, and pumpkin were grained by a fine grinding machine (Dxfill, Model DXM-500, China) at speed level 2 for 2 min.

The appropriate TJSC formula from (1) was selected and investigated. The completely randomized design (CRD) was used for studying. The effect of different types of flour consisting of wheat flour (control), non-glutinous rice flour, glutinous rice flour, potato flour, tapioca flour, durian rind flour, purple sweet potato flour, banana flour, and pumpkin flour on the quality of TJSC was studied. The production method of TJSC was produced according to (1).

All formulas of TJSC were observed. The viscosity, hardness, and color were investigated and the analysis methods have been described above. Sensory evaluation by 30 untrained panelists was investigated. The appropriate flour in the replacement of wheat flour was selected for healthy TJSC production in the next step.

Study of the effect of corn milk instead of coconut milk on the quality of TJSC

Corn milk was prepared. Fresh sweet corn (Zea mays L. var. rugosa Bonaf.) grain was separated. The ratio of water to corn grains was 1:2 (W/W). It was mashed and mixed in a juice blender (Philips, HR-2056, China) at speed level 2 for $1 \mathrm{~min}$ of the 3rd round. Next, it was separated by a thin white cloth.

The five formulas of TJSC were studied. The ratio of coconut milk to corn milk were 100:0, 75:25, 50:50, 25:75, and 0:100, respectively. The flour for the TJSC production was selected from (2). The production method of TJSC was produced according to (1). All formulas of TJSC were observed. The viscosity, hardness, and color were investigated and the analysis methods have been described above. Sensory evaluation by 30 untrained panelists was investigated. The suitable ratio of coconut milk to corn milk was selected for healthy TJSC production in the next step. 
http://wjst.wu.ac.th

\section{Study of the effect of stevia leaf extract instead of sugar on the quality of TJSC}

Stevia leaf extract was bought from the farmer at Khao Chakan district in Sakaeo province. The total soluble solid content of stevia leaf extract was 0.8. The six formulas of TJSC were studied. The ratio of sugar to stevia leaf extract were 100:0, 90:10, 80:20, 70:30, 60:40 and 50:50, respectively. The suitable ratio of coconut milk to corn milk was selected from (3). The production method of TJSC was produced according to (2). All formulas of TJSC were observed. The viscosity, hardness, total soluble solid content, and color were investigated and the analysis methods have been described above. Sensory evaluation by 30 untrained panelists was investigated. The suitable ratio of sugar to stevia leaf extract was selected for healthy TJSC production in the next step.

\section{Study of the effect of herbal supplement on the sensory acceptance of TJSC}

Young ginger (Zingiber officinale Roscoe), fresh trunk young galangal (Alpinia galanga (L.) Willd.), young lemongrass (Cymbopogon citratus), sunchoke (Helianthus tuberosus L.), and turmeric (Curcuma longa L.) were prepared. First of all, the herbs were washed and cut into small pieces. Next, it was dried in a hot air oven at $60^{\circ} \mathrm{C}$ for $10 \mathrm{~h}$. Then, dried herbs were grained by a fine grinding machine (Dxfill, Model DXM-500, China) at speed level 2 for 2 min. It was kept at a sealed container until used.

The $0.3 \%$ herbal powder was added to TJSC production. It was compared with the control formula without the addition of herbs. The suitable ratio of sugar to stevia leaf extract was selected from (4). The production method of TJSC was produced according to (1). All formulas of TJSC were observed. Sensory evaluation by 30 untrained panelists was investigated. The control formula (without the herb) and the suitable formula in 1 were determined moisture, protein, fat, carbohydrate, ash, and total energy [13].

\section{Statistical analysis}

The statistical technique one-way ANOVA was used for calculating. Duncan's new multiple-range Test (DMRT) was used to compare the difference in the average values at the $95 \%$ confidence level [14].

\section{Results and discussion}

Effects of coconut milk, sugar, and wheat flour on the quality of TJSC

The appearance of all 13 formulas was observed (Figure 1). It was found that all 13 formulas had a different appearance. The texture of formulas $1,6,8$, and 10 before baking was sticky that were difficult to form. These were milky white, hard outer surface, and quite sticky inside after baking. The texture of formulas 2, 11, and 13 before baking was very mushy that were difficult to form. These were milky white, soft outer surface, and very soft inside after baking. Interestingly, formula 3 was a very good texture and easy form. It was milky white, crispy outer surface, and soft inside after baking. It was just as good as the TJSC that was marketed in the market. Formula 4 was easy forming. It was milky white, soft outer surface and inside after baking. Formulas 5 and 7 were messy and cannot form. These were milky white, very soft outer surface, and inside after baking. Formulas 9 and 12 were liquid and cannot form. These were a yellowish-brown liquid. The appearance of all 13 formulas was a result of coconut milk, sugar, and wheat flour. Moreover, the thermal process for mixing and drying caused physiological changes such as gelatinization of flour, browning reaction and sugar crystallization, etc. [15]. 


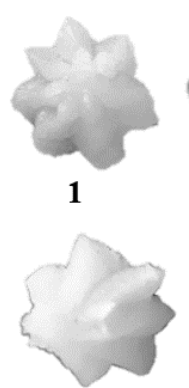

8

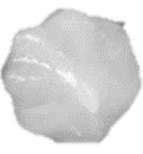

2

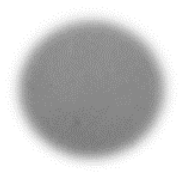

9

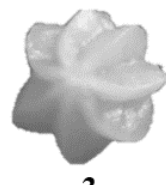

3

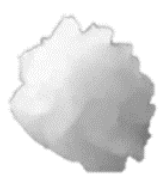

10

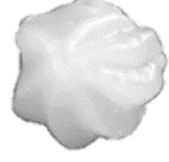

4

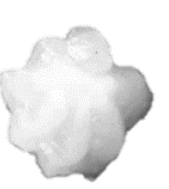

11

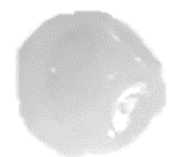

5

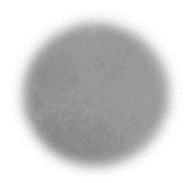

12

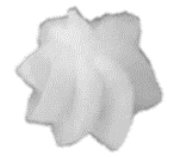

6

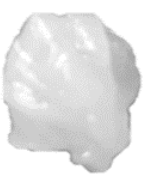

13

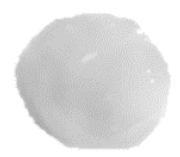

7

Figure 1 The appearance of TJSC from thirteen formulations.

The weight loss, viscosity, hardness, total soluble solids, and color of TJSC from the contour plots surface are shown in Figure 2. It was found that all 13 formulas had different weight loss with statistical significance at the $95 \%$ confidence level $(p \leq 0.05)$. The weight loss of TJSC increased with increasing coconut milk content and decreased with increasing the amount of sugar. As a result, coconut milk is a liquid in which water is the main component. Drying caused free water in the coconut milk to evaporate easily. The molecules of water in a liquid state around the surface of TJSC are discharged into gaseous. Specifically, the motion and collision of water molecules cause the energy exchange with each other. Furthermore, the liquid molecules have different kinetic energy from the average kinetic energy. Molecules with high kinetic energy overcome the gravitational attraction between molecules, and loose from the surface of the liquid become gas [15]. Therefore, formulas with high amounts of coconut milk were more likely to free evaporation than formulas with high sugar and wheat flour. It results in a formula that had a high amount of coconut milk with a high percentage of weight loss during baking.

All 13 recipes of TJSC had differences in viscosity and hardness $(p \leq 0.05)$. It was found that the viscosity and hardness of TJSC varied with the amount of wheat flour. It may be due to the properties of the flour when dissolved in water and heated that the starch is gelatinized. In general, the molecules of starch consist of a large number of hydroxyl groups with hydrogen bonds. It had hydrophobic properties. Consequently, the starch structure was in the form of mesh. It was difficult to dissolve in cold water. When the starch solution was heated, a hydrogen bond was released. The starch structure absorbed water and swell. Therefore, the viscosity of the flour solution increased. Because free water around the starch structure was less, it is difficult to move that with increasing viscosity [17]. In addition, flour concentration was the important factor that affected on viscosity and hardness of TJSC. The viscosity varied directly with the amount of flour concentration in the solution [18]. Increasing viscosity, the internal structure of TJSC was binding sticks together after drying that resulting in increased hardness.

All 13 recipes had differences in total soluble solid $(p \leq 0.05)$. It was found that total soluble solids varied directly with the amount of sugar. White sugar is an energy sucrose that is in crystal form. Moreover, it is a carbohydrate that has a sweet taste and dissolves well in water. Sugar analysis relies on the solubility property. The concentration of the sugar solution is related to the specific gravity, or measure the light deviation with a refractometer [19]. Accordingly, the recipes with a high amount of sugar increase the sweetness of TJSC.

The color of all 13 recipes was different $(p \leq 0.05)$. It was found that the $\mathrm{L} *$ (brightness) varied directly with the amount of flour, the $\mathrm{a} *$ value was in the red range and the $\mathrm{b} *$ values were in the yellow range. When the sugar content increased, the $\mathrm{a} *$ and $\mathrm{b} *$ values tended to increase that is approaching the yellow-red range. It corresponds to the color observed for the appearance of TJSC. The recipes that have a high amount of sugar will have a yellow to a darker brown color. Changing the color of TJSC may be caused by changes in the chemical composition of coconut milk, sugar, and flour. For example, the structure of the amylose which is a component in the flour is changed during gelatinization. The gelatinization of flour is opaque and a strong gel. The Maillard reaction is occurring during the mixed and 
http://wjst.wu.ac.th

dried process. It is a reaction between protein or amino acids and sugar under high-temperature conditions [15]. Interestingly, formula 9 (40\% of sugar and $60 \%$ of coconut milk) and formula 12 (30\% of sugar and $70 \%$ of coconut milk) were investigated. TJSC without wheat flour was milky white liquid before heating and was a yellowish-brown liquid after heating. It may be the result of the Maillard reaction between sugar and protein or amino acids in coconut milk under high temperatures. Furthermore, coconut milk has $3-4 \%$ of the protein and the globulin is main protein. Coconut protein consists of both many essential and non-essential amino acids which are high glutamic acid and arginine [20].
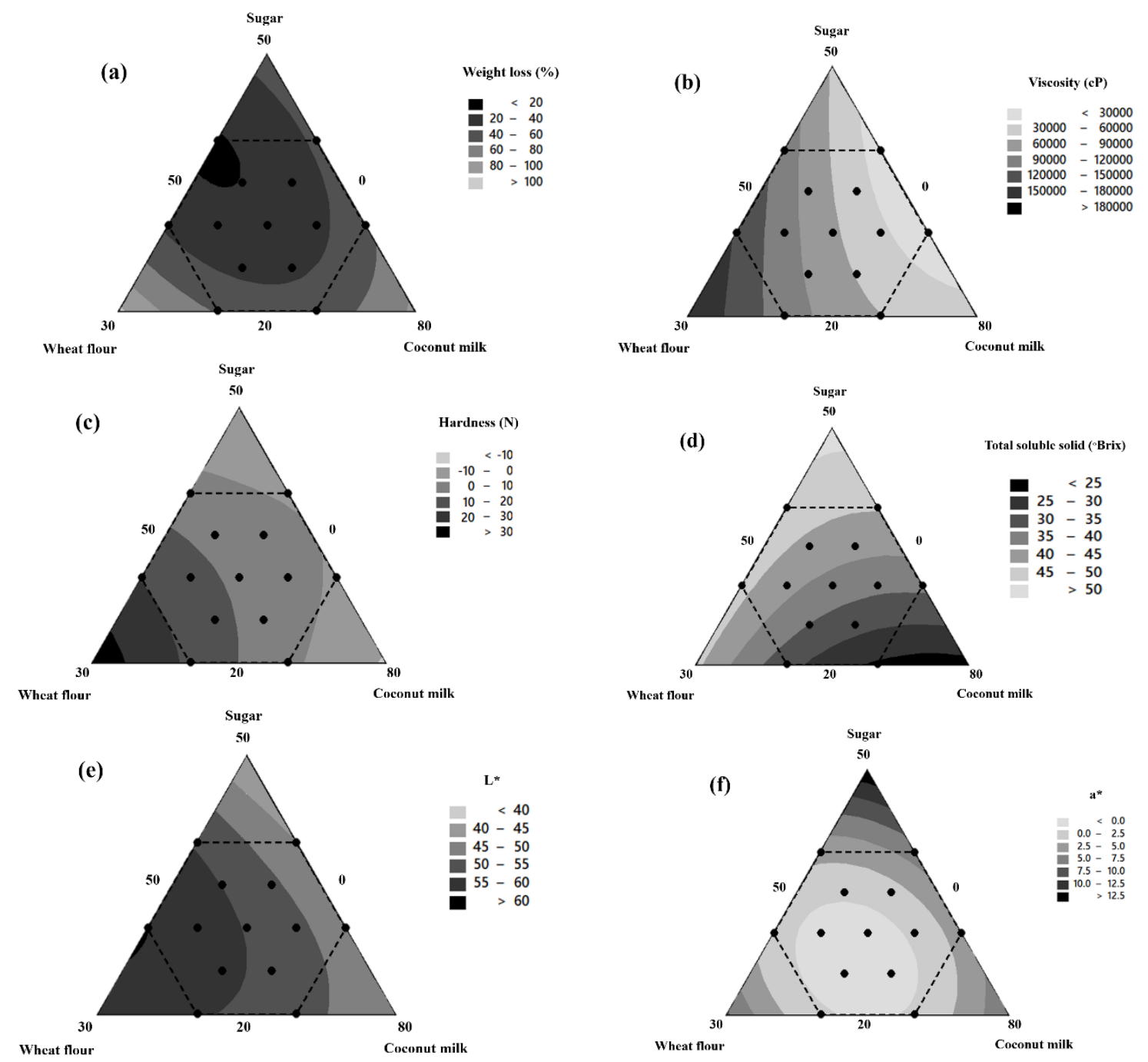

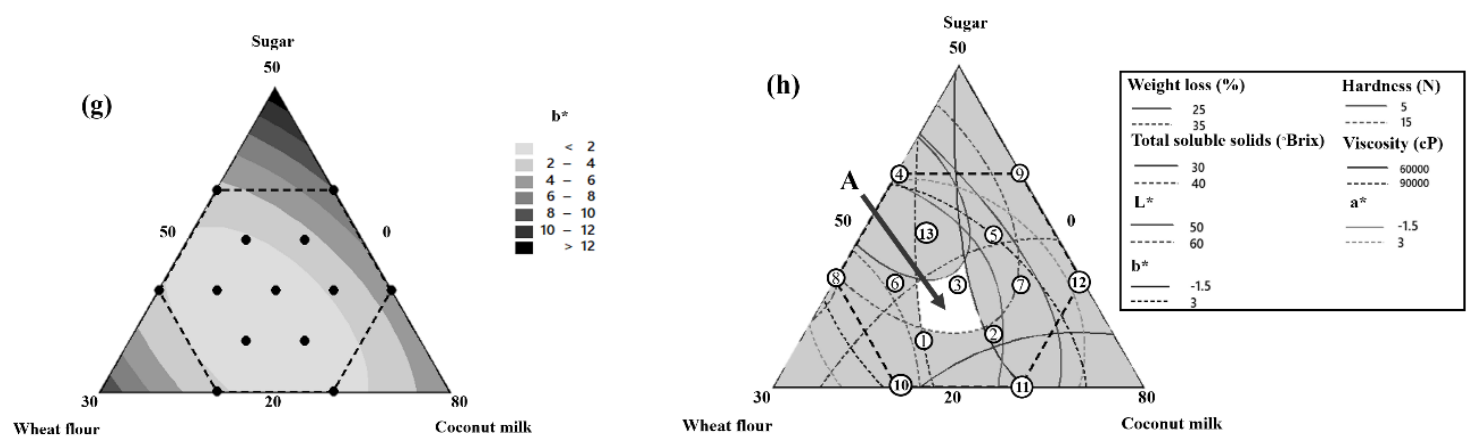

Figure 2 Weight loss (a), viscosity (b), hardness (c), total soluble solid (d), and color (e-g) of TJSC by a 3-component mixture design and contour plot for optimum overlapping (A) of TJSC formulations (h).

The weight loss, viscosity, hardness, total soluble solids, and colors were used to create a contour plot for finding the optimum overlapping areas (Figure 2(a) - 2(g)). The weight loss $(25-35 \%)$, viscosity $(60000-90000 \mathrm{cP})$, hardness value $(5-15 \mathrm{~N})$, total soluble solids $\left(30-40{ }^{\circ} \mathrm{Brix}\right)$, and $\mathrm{L} *$ value $(50-60), a *$ value $(-1.5-3)$, and $b$ value $*(-1.5-3)$ were a criterion for selecting the optimum overlapping areas. It was found that the optimum overlapping areas (the letter A) in Figure 2(h)was formula $3(60 \%$ of coconut milk, $30 \%$ of sugar, and $10 \%$ of wheat flour). All data and sensory evaluation results of TJSC were considered together (Table 2). The results showed that the average sensory acceptance rate of 30 general consumers by the 9-point hedonic scale in terms of appearance, flavor, texture, taste, and overall liking were statistically significant differences $(p \leq 0.05)$. The formula 3 had the highest mean score of appearance $(7.60 \pm 0.67)$, flavor $(7.03 \pm 0.61)$, texture $(7.73 \pm 0.45)$, taste $(7.77 \pm 0.82)$ and overall liking $(7.63 \pm 0.76)$, which was a moderate level. It corresponded to the results from appearance observation. Formula 3 was a very good texture and easy form. It was milky white, crispy outer surface, and soft inside after baking. The appearance observation, weight loss, viscosity, hardness, total soluble solids, colors, and sensory evaluation were considered together for selecting the optimum formula. Formula 3 was suitable for using as a prototype for healthy TJSC production in the next step.

Table 2 The liking score $(n=30)$ for thirteen formulations of TJSC.

\begin{tabular}{llllll}
\hline \multirow{2}{*}{ Formulation } & \multicolumn{5}{c}{ Attribute } \\
\cline { 2 - 5 } & Appearance & Flavor & Texture & Taste & Overall liking \\
\hline 1 & $5.80 \pm 0.71^{\mathrm{c}}$ & $6.47 \pm 0.68^{\mathrm{bc}}$ & $5.50 \pm 0.57^{\mathrm{c}}$ & $6.27 \pm 0.69^{\mathrm{cd}}$ & $6.07 \pm 0.69^{\mathrm{c}}$ \\
2 & $5.10 \pm 0.80^{\mathrm{d}}$ & $6.77 \pm 0.73^{\mathrm{ab}}$ & $5.43 \pm 0.50^{\mathrm{c}}$ & $5.77 \pm 1.01^{\mathrm{de}}$ & $5.67 \pm 0.99^{\mathrm{c}}$ \\
3 & $7.60 \pm 0.67^{\mathrm{a}}$ & $7.03 \pm 0.61^{\mathrm{a}}$ & $7.73 \pm 0.45^{\mathrm{a}}$ & $7.77 \pm 0.82^{\mathrm{a}}$ & $7.63 \pm 0.76^{\mathrm{a}}$ \\
4 & $4.13 \pm 1.14^{\mathrm{e}}$ & $4.67 \pm 1.52^{\mathrm{d}}$ & $3.60 \pm 1.25^{\mathrm{d}}$ & $3.33 \pm 1.24^{\mathrm{f}}$ & $3.57 \pm 1.19^{\mathrm{d}}$ \\
5 & $2.10 \pm 1.27^{\mathrm{f}}$ & $3.43 \pm 1.43^{\mathrm{e}}$ & $1.87 \pm 0.90^{\mathrm{e}}$ & $2.60 \pm 1.19^{\mathrm{g}}$ & $2.47 \pm 0.97^{\mathrm{e}}$ \\
6 & $7.47 \pm 0.78^{\mathrm{a}}$ & $6.43 \pm 0.82^{\mathrm{bc}}$ & $6.47 \pm 0.94^{\mathrm{b}}$ & $7.07 \pm 0.87^{\mathrm{b}}$ & $6.83 \pm 1.12^{\mathrm{b}}$ \\
7 & $2.30 \pm 1.47^{\mathrm{f}}$ & $4.40 \pm 0.93^{\mathrm{d}}$ & $1.73 \pm 0.69^{\mathrm{e}}$ & $2.73 \pm 1.11^{\mathrm{g}}$ & $2.40 \pm 0.89^{\mathrm{e}}$ \\
8 & $5.73 \pm 0.64^{\mathrm{c}}$ & $6.17 \pm 0.59^{\mathrm{bc}}$ & $5.43 \pm 0.57^{\mathrm{c}}$ & $6.13 \pm 0.73^{\mathrm{cde}}$ & $5.80 \pm 0.66^{\mathrm{c}}$ \\
9 & $1.07 \pm 0.25^{\mathrm{g}}$ & $2.80 \pm 1.00^{\mathrm{f}}$ & $1.17 \pm 0.38^{\mathrm{f}}$ & $1.50 \pm 0.86^{\mathrm{h}}$ & $1.37 \pm 0.89^{\mathrm{f}}$ \\
10 & $6.13 \pm 0.94^{\mathrm{c}}$ & $6.37 \pm 0.67^{\mathrm{bc}}$ & $5.30 \pm 0.65^{\mathrm{c}}$ & $5.73 \pm 0.69^{\mathrm{e}}$ & $5.60 \pm 0.72^{\mathrm{c}}$ \\
11 & $5.93 \pm 0.94^{\mathrm{c}}$ & $6.50 \pm 0.78^{\mathrm{bc}}$ & $5.57 \pm 0.86^{\mathrm{c}}$ & $6.03 \pm 0.93^{\text {cde }}$ & $5.90 \pm 0.99^{\mathrm{c}}$ \\
12 & $1.10 \pm 0.31^{\mathrm{g}}$ & $2.83 \pm 1.05^{\mathrm{f}}$ & $1.17 \pm 0.46^{\mathrm{f}}$ & $1.43 \pm 0.82^{\mathrm{h}}$ & $1.27 \pm 0.74^{\mathrm{f}}$ \\
13 & $6.67 \pm 1.24^{\mathrm{b}}$ & $6.03 \pm 0.93^{\mathrm{bc}}$ & $6.67 \pm 1.12^{\mathrm{b}}$ & $6.47 \pm 1.04^{\mathrm{c}}$ & $6.57 \pm 1.22^{\mathrm{b}}$ \\
\hline
\end{tabular}

note: mean $\pm \mathrm{SD},{ }^{\mathrm{a}-\mathrm{h}}$ means within each column indicate significant differences $(\mathrm{p} \leq 0.05)$ using Duncan's multiple range test. 


\section{Effect of different types of flour in substitution of wheat flour on the quality of TJSC}

The appearance observation of TJSC using different types of flour consisting of wheat (control formula), non-glutinous rice, glutinous rice, potato, tapioca, durian rind, purple sweet potato, banana, and pumpkin flour was shown in Figure 3. The results showed that TJSC from 9 types of flour had a different appearance. TJSC from non-glutinous rice flour was easy forming, and not too sticky or messy of texture. It was milky white, crispy outer surface, and soft inside after baking. It was just as well as the texture of TJSC from wheat flour. TJSC from glutinous rice flour, potato flour, and tapioca flour were difficult to form and unstable. These were milky white, very soft outer surface, and inside after baking. TJSC from durian rind flour was easy forming and not sticky. It was a light brown color, very hard, and a durian fragrance after baking. TJSC from purple sweet potato flour was difficult to form and unstable. It was a dark purple color, very soft, and a purple sweet potato fragrance after baking. TJSC from banana flour was a difficult forming. It was a light brown color, quite sticky, and a banana fragrance after baking. TJSC from pumpkin flour was easy forming and not stickiness. It was a dark yellow color, very hard and a pumpkin fragrance after baking.

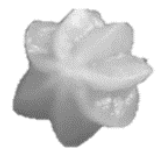

Wheat

flour
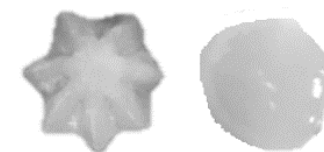

Non-glutinous Glutinous

rice flour rice flour

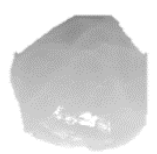

Potato

flour

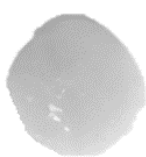

Tapioca

flour

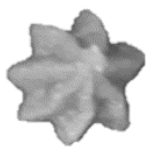

Durian rind

flour

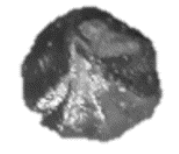

Purple sweet

potato flour
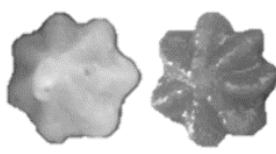

Banana Pumpkin

flour flour

Figure 3 Appearance of TJSC from different flours.

The effect of different types of flour on viscosity, hardness, and color of TJSC are shown in Table 3. It was found that TJSC prepared from different flours had different hardness, viscosity, and color with statistical significance at the $95 \%$ confidence level $(p \leq 0.05)$. TJSC from durian rind flour had the highest hardness. TJSC from tapioca flour had the highest viscosity. In terms of color, TJSC from purple sweet potato flour had the lowest brightness. TJSC from pumpkin flour had the highest of $\mathrm{a}^{*}$ and $\mathrm{b}^{*}$ value which was values range from yellow to red color and appearance consistent with observation.

The different chemical composition of each flour was affecting on physical and chemical properties of flour. The type of flour was an important factor affecting on the viscosity of flour. In terms of viscosity of TJSC during agitation, tapioca flour has the highest viscosity, potato flour, and purple sweet potato flour, respectively. Because all 3 types of flour were the group of tuber plants and large molecular size. Flour absorbed water during heat and expand.

The water around the flour structure decreased that caused the difficulty to move. Furthermore, it had high viscosity. In addition, other factors affected the viscosity such as molecule size of flour, the ratio of amylose to amylopectin and temperature, etc. [17]. In terms of hardness, TJSC from durian rind flour had the highest hardness. It may be the durian rind flour had high cellulose and polysaccharides that It had a good ability to absorb moisture. When TJSC was dried, the moistures were less. The internal structure of TJSC was high cohesive that hardness increased. It was consistent with studying the effects of using durian rind flour instead of wheat flour in tart products. It was found that the hardness of tart increased when the amount of durian rind flour increased [21]. TJSC had different colors because each type of flour had a unique color that it has different pigments. Wheat flour, non-glutinous flour, glutinous rice flour, potato flour, and tapioca flour were used in this study were commercial flour. Some pigments were eliminated during the flour manufacturing process. These were white color same as general trade flour in the market. Likewise, durian rind flour and banana flour were a light-yellow color that pigment was not eliminated during the flour process. When it was used to produce TJSC, it was the yellow-brown color. Besides, the browning reaction involving enzymes may result in brown color. It is an oxidation 
http://wjst.wu.ac.th

reaction that occurs when plant cells are damaged. The enzyme, substrate, and oxygen were reacting. Monophenols are oxidized to diphenols that colorless. Then, it is oxidized to o-quinones which it reacts with amino acids or proteins to brown substances, and it collects together as a large polymer and brown color [15]. TJSC from purple sweet potato flour was a purple color. Purple sweet potato contains anthocyanin that is a water-soluble pigment giving red to blue colors. Anthocyanin is changed according to the $\mathrm{pH}$ conditions. Therefore, it is a $\mathrm{pH}$ indicator. It is a red color at a low $\mathrm{pH}$ value, blue at a neutral $\mathrm{pH}$, and purple at high $\mathrm{pH}$. Many factors are affecting the color and stability of anthocyanins such as structure, temperature, $\mathrm{pH}$, etc. [22]. TJSC from pumpkin flour was drake yellow color. An important antioxidant in pumpkin is beta carotene. In general, 100 grams of pumpkin flesh contains $1.4-8.4 \mathrm{mg}$ of beta carotene. Carotenoids which are yellow, orange, red, and orange-red pigment are 19 types. It contains $74 \%$ beta carotene [23].

Table 3 The effect of different flours on the physical properties of TJSC.

\begin{tabular}{llllll}
\hline \multirow{2}{*}{ Types of flour } & \multirow{2}{*}{ Viscosity $(\mathbf{c P})$} & \multirow{2}{*}{ Hardness $(\mathbf{N})$} & \multicolumn{2}{c}{ Color } \\
\cline { 4 - 6 } & & $\mathbf{L}^{*}$ & $\mathbf{a}^{*}$ & $\mathbf{b}^{*}$ \\
\hline Wheat & $85300 \pm 265^{\mathrm{f}}$ & $12.57 \pm 0.04^{\mathrm{c}}$ & $53.35 \pm 0.28^{\mathrm{d}}$ & $-0.33 \pm 0.09^{\mathrm{g}}$ & $1.12 \pm 0.10^{\mathrm{g}}$ \\
Non-glutinous rice & $85267 \pm 681^{\mathrm{f}}$ & $12.61 \pm 0.03^{\mathrm{c}}$ & $48.98 \pm 0.06^{\mathrm{f}}$ & $-1.10 \pm 0.00^{\mathrm{h}}$ & $-0.37 \pm 0.02^{\mathrm{h}}$ \\
Glutinous rice & $111667 \pm 764^{\mathrm{e}}$ & $1.84 \pm 0.04^{\mathrm{f}}$ & $56.48 \pm 0.18^{\mathrm{c}}$ & $1.72 \pm 0.01^{\mathrm{f}}$ & $3.20 \pm 0.02^{\mathrm{e}}$ \\
Potato & $151500 \pm 500^{\mathrm{b}}$ & $1.32 \pm 0.04^{\mathrm{g}}$ & $57.35 \pm 0.16^{\mathrm{b}}$ & $2.10 \pm 0.03^{\mathrm{e}}$ & $1.91 \pm 0.05^{\mathrm{f}}$ \\
Tapioca & $187333 \pm 577^{\mathrm{a}}$ & $1.24 \pm 0.04^{\mathrm{h}}$ & $57.30 \pm 0.09^{\mathrm{b}}$ & $2.07 \pm 0.02^{\mathrm{e}}$ & $3.63 \pm 0.01^{\mathrm{d}}$ \\
Durian rind & $55333 \pm 208^{\mathrm{g}}$ & $25.32 \pm 0.02^{\mathrm{a}}$ & $58.18 \pm 0.15^{\mathrm{a}}$ & $4.32 \pm 0.24^{\mathrm{c}}$ & $12.53 \pm 0.16^{\mathrm{b}}$ \\
Purple sweet potato & $121967 \pm 451^{\mathrm{c}}$ & $5.35 \pm 0.05^{\mathrm{e}}$ & $28.75 \pm 0.09^{\mathrm{h}}$ & $9.06 \pm 0.03^{\mathrm{b}}$ & $-1.31 \pm 0.05^{\mathrm{i}}$ \\
Banana & $115400 \pm 400^{\mathrm{d}}$ & $18.30 \pm 0.05^{\mathrm{b}}$ & $50.64 \pm 0.32^{\mathrm{e}}$ & $2.56 \pm 0.05^{\mathrm{d}}$ & $4.26 \pm 0.07^{\mathrm{c}}$ \\
Pumpkin & $35667 \pm 208^{\mathrm{h}}$ & $8.72 \pm 0.03^{\mathrm{d}}$ & $36.14 \pm 0.15^{\mathrm{g}}$ & $12.30 \pm 0.45^{\mathrm{a}}$ & $15.14 \pm 0.40^{\mathrm{a}}$ \\
\hline
\end{tabular}

note: mean $\pm \mathrm{SD},{ }^{\mathrm{a}-\mathrm{i}}$ means within each column indicate significant differences $(p \leq 0.05)$ using Duncan's multiple range test.

A sensory evaluation of consumer acceptance testing with 30 untrained panelists using the 9-point hedonic scale was investigated. TJSC from wheat flour (control formula) was an average score of appearance $(7.60 \pm 0.67)$, flavor $(7.03 \pm 0.61)$, texture $(7.73 \pm 0.45)$, taste $(7.77 \pm 0.82)$, and overall liking $(7.63 \pm 0.76)$, respectively. TJSC from non-glutinous rice flour was an average score of appearance $(7.57$ $\pm 0.63)$, flavor $(7.10 \pm 0.66)$, texture $(7.67 \pm 0.48)$, taste $(7.73 \pm 0.83)$, and overall liking $(7.60 \pm 0.77)$, respectively. It is no different from the wheat flour formula $(p>0.05)$ and it has a higher average score than other flour. Appearance observation, viscosity, hardness, and sensory evaluation were considered together. TJSC from non-glutinous rice flour was a good appearance and was a high sensory acceptable score, that was no different from TJSC of wheat flour. Therefore, non-glutinous rice flour is the satiable formula for healthy TJSC production in the next step.

\section{Effect of corn milk instead of coconut milk on the quality of TJSC}

Effect of corn milk instead of coconut milk on the appearance of TJSC was observed. The results showed that the intensity of the yellow color and corn fragrant increased when the ratio of corn milk increased. TJSC with 75 and $100 \%$ corn milk were observed. These were yellow in color, hard outer surface, and sticky inside after baking. Obviously, these were hard to remove from the baking tray and were easily deformed. On the other hand, TJSC 0,25 , and $50 \%$ corn milk were a good texture. These were white to yellow color, crispy outer surface, and soft inside after baking. These were easy to remove from the baking tray and stable.

Effects of corn milk instead of coconut milk on viscosity, hardness, and color of TJSC are shown in Table 4. It was found that the viscosity and hardness of TJSC tended to increase when the amount of corn 
http://wjst.wu.ac.th

milk increased. TJSC with $100 \%$ corn milk had the highest brightness, a * and $\mathrm{b} *$. TJSC with the increasing amount of corn milk which was in the yellow to a red color consistent with appearance observation. The difference in chemical composition of coconut milk and corn milk effect on viscosity and hardness of TJSC. Generally, coconut milk is composed of approximately $50 \%$ water and $30-40 \%$ fat. Coconut milk is classified as a colloidal type of oil in water emulsion. The emulsion system consists of coconut oil particles suspended in the water phase. In addition, coconut protein also acts as the main natural emulsifier. It helps coconut oil particles suspended in the water. The charge of the protein prevents the aggregation of oil particles [24]. The satiable amount of coconut milk affects the good quality of TJSC that is easy to be removed from the baking tray and has a good texture. Corn milk has high moisture content and contains lower fat than coconut milk [10]. At this point, TJSC with 75 and 100 $\%$ corn milk was hard to be removed from the baking tray, hard outer surface, and sticky inside after baking. In terms of color, corn milk was yellow in color which had yellow pigment. It contains about 1 in 3 carotenes and about 2 in 3 xanthophyll. The important carotenoids are zeaxanthin, cryptoxanthin, betacarotene, and lutein [10].

Sensory evaluation showed that the average score in all attributes tended to decrease as the amount of corn milk increased. TJSC with $25 \%$ corn milk was an average score in appearance $(7.83 \pm 0.75)$, flavor $(7.50 \pm 0.78)$, texture $(7.73 \pm 0.52)$, taste $(7.87 \pm 0.86)$, and overall liking $(7.73 \pm 0.83)$, respectively. Likewise, TJSC with $50 \%$ corn milk was an average score in appearance $(7.90 \pm 0.76)$, flavor $(7.70 \pm$ $0.88)$, texture $(7.63 \pm 0.56)$, taste $(7.93 \pm 0.87)$, and overall liking $(7.80 \pm 0.85)$, respectively. TJSC with 25 and $50 \%$ corn milk have an average score in all attributes not different from TJSC with $100 \%$ coconut milk $(\mathrm{p}>0.05)$. TJSC with $0 \%$ coconut milk has the lowest average score in appearance $(5.80 \pm$ $1.42)$, flavor $(7.33 \pm 0.76)$, texture $(4.67 \pm 1.45)$, taste $(7.00 \pm 1.51)$, and overall liking $(5.80 \pm 1.42)$, respectively. The appearance observation, viscosity, hardness, and sensory evaluation were considered together. TJSC with $50 \%$ corn milk was selected for the development in the next step.

Table 4 The physical properties of TJSC from various ratios of coconut milk with corn milk.

\begin{tabular}{lllccc}
\hline \multirow{2}{*}{$\begin{array}{l}\text { The ratio of coconut } \\
\text { milk to corn milk }\end{array}$} & \multirow{2}{*}{ Viscosity $(\mathbf{c P})$} & \multirow{2}{*}{ Hardness $(\mathbf{N})$} & \multicolumn{3}{c}{ Color } \\
\cline { 4 - 6 } & & $\mathbf{L}^{*}$ & $\mathbf{a}^{*}$ & $\mathbf{b}^{*}$ \\
$75: 25$ & $85267 \pm 681^{\mathrm{e}}$ & $12.61 \pm 0.03^{\mathrm{e}}$ & $48.98 \pm 0.06^{\mathrm{e}}$ & $-1.10 \pm 0.00^{\mathrm{e}}$ & $-0.37 \pm 0.02^{\mathrm{e}}$ \\
$50: 50$ & $90333 \pm 289^{\mathrm{d}}$ & $12.81 \pm 0.07^{\mathrm{d}}$ & $51.60 \pm 0.19^{\mathrm{d}}$ & $0.09 \pm 0.02^{\mathrm{d}}$ & $2.83 \pm 0.07^{\mathrm{d}}$ \\
$25: 75$ & $95000 \pm 500^{\mathrm{c}}$ & $13.05 \pm 0.05^{\mathrm{c}}$ & $54.70 \pm 0.06^{\mathrm{c}}$ & $0.17 \pm 0.02^{\mathrm{c}}$ & $3.89 \pm 0.05^{\mathrm{c}}$ \\
$0: 100$ & $97133 \pm 551^{\mathrm{b}}$ & $16.19 \pm 0.04^{\mathrm{b}}$ & $56.60 \pm 0.12^{\mathrm{b}}$ & $0.27 \pm 0.02^{\mathrm{b}}$ & $4.43 \pm 0.20^{\mathrm{b}}$ \\
\hline
\end{tabular}

note: mean $\pm \mathrm{SD}$, ${ }^{\mathrm{a}-\mathrm{e}}$ means within each column indicate significant differences $(p \leq 0.05)$ using Duncan's multiple range tests.

\section{Effect of stevia leaf extract instead of sugar on the quality of TJSC}

Effect of stevia leaf extract instead of sugar on the appearance of TJSC was observed. It was found that TJSC with 30, 40, and $50 \%$ leaf extract was quite dry, shrink, and high hardness. Effect of stevia leaf extract instead of sugar on viscosity, hardness, total soluble solid, and color of TJSC shows in Table 5. It was found that the viscosity and total soluble solid of TJSC tended to decrease when the amount of stevia leaf extract increased. The hardness, brightness, $a *$ and $b *$ value varied directly with the amount of stevia leaf extract. Both sugar and stevia leaf extract are sweeteners. However, they have different characteristics and properties. White sugar is solid and has well capable of absorbing moisture. It has high total soluble solids. The characteristics and properties of sugar affects the viscosity of TJSC that the crystallization is occurred after drying [19]. It made the best texture which crispy on the outside and soft inside. Stevia leaf extract is a clear liquid, no color, and low total soluble solid (0.8 Brix). The viscosity 
http://wjst.wu.ac.th

and total soluble solid of TJSC decreased when the amount of stevia leaf extract increased. The moisture was removed after drying. TJSC with 30, 40 and 50\% leaf extract was quite dry, shrink, high hardness, and low crystallization. The lowest hardness of TJSC at $100 \%$ of stevia leaf extract. It corresponds to the report of Chieovej [25]. The effect of stevia leaf extract instead of sugar on the quality of the gub dessert product was studied. The result showed that the crispness of the gub dessert product decreased when the amount of stevia leaf extract increased.

Sensory evaluation showed that the average score in all attributes tended to decrease as the amount of stevia leaf extract increased. TJSC with $10 \%$ stevia leaf extract was an average score in appearance $(7.83 \pm 0.75)$, flavor $(7.57 \pm 0.77)$, texture $(7.57 \pm 0.50)$, taste $(7.77 \pm 0.73)$, and overall liking $(7.70 \pm$ $0.79)$, respectively. Similarly, TJSC with $20 \%$ stevia leaf extract was an average score in appearance $(7.67 \pm 0.71)$, flavor $(7.53 \pm 0.82)$, texture $(7.50 \pm 0.51)$, taste $(7.67 \pm 0.76)$, and overall liking $(7.50 \pm$ $0.68)$, respectively. TJSC with 10 and $20 \%$ stevia leaf extract have an average score in all attributes not different from TJSC with $100 \%$ sugar $(\mathrm{p}>0.05)$. TJSC with $50 \%$ stevia leaf extract has the lowest average score in appearance $(4.70 \pm 0.92)$, flavor $(6.60 \pm 1.28)$, texture $(4.63 \pm 0.89)$, taste $(4.57 \pm 0.82)$, and overall liking $(4.07 \pm 1.23)$, respectively. Obviously, using high amounts of stevia leaf extract in TJSC had a bitter taste. Stevia has a lot of phenolic compounds. Likewise, stevia leaf extract in addition to the taste of Kanomtian crust was reported. The bitterness of Kanomtian crust in the mouth felt increased when stevia leaf extract increased [26]. The appearance observation, viscosity, hardness, total soluble solid, and sensory evaluation were considered together. TJSC with $20 \%$ stevia leaf extract was selected for the development in the next step.

Table 5 The physical properties of TJSC from various ratios of sugar with stevia.

\begin{tabular}{cllllll}
\hline \multirow{2}{*}{$\begin{array}{c}\text { The ratio of } \\
\text { sugar to stevia }\end{array}$} & $\begin{array}{l}\text { Viscosity } \\
(\mathbf{c P})\end{array}$ & $\begin{array}{l}\text { Hardness } \\
\mathbf{( N )}\end{array}$ & $\begin{array}{l}\text { Total soluble } \\
\text { solid }\left({ }^{\mathbf{0} B r i x}\right)\end{array}$ & \multicolumn{3}{c}{ Color } \\
\cline { 5 - 7 } & $\mathbf{L}^{*}$ & $\mathbf{a}^{*}$ & $\mathbf{b}^{*}$ \\
\hline $90: 10$ & $95000 \pm 500^{\mathrm{a}}$ & $13.05 \pm 0.05^{\mathrm{f}}$ & $37.05 \pm 0.05^{\mathrm{a}}$ & $54.70 \pm 0.06^{\mathrm{e}}$ & $0.17 \pm 0.02^{\mathrm{f}}$ & $3.89 \pm 0.05^{\mathrm{e}}$ \\
$80: 20$ & $90400 \pm 173^{\mathrm{b}}$ & $13.15 \pm 0.05^{\mathrm{e}}$ & $31.15 \pm 0.03^{\mathrm{b}}$ & $56.70 \pm 0.06^{\mathrm{d}}$ & $0.27 \pm 0.02^{\mathrm{e}}$ & $4.26 \pm 0.02^{\mathrm{d}}$ \\
$70: 30$ & $83000 \pm 866^{\mathrm{c}}$ & $13.36 \pm 0.02^{\mathrm{d}}$ & $27.52 \pm 0.03^{\mathrm{c}}$ & $58.37 \pm 0.53^{\mathrm{c}}$ & $0.74 \pm 0.04^{\mathrm{d}}$ & $4.74 \pm 0.04^{\mathrm{c}}$ \\
$60: 40$ & $79867 \pm 709^{\mathrm{e}}$ & $19.15 \pm 0.04^{\mathrm{b}}$ & $18.18 \pm 0.03^{\mathrm{e}}$ & $60.70 \pm 0.17^{\mathrm{a}}$ & $1.03 \pm 0.02^{\mathrm{b}}$ & $5.00 \pm 0.01^{\mathrm{b}}$ \\
$50: 50$ & $79300 \pm 200^{\mathrm{e}}$ & $21.15 \pm 0.04^{\mathrm{a}}$ & $15.63 \pm 0.03^{\mathrm{f}}$ & $60.95 \pm 0.05^{\mathrm{a}}$ & $1.13 \pm 0.02^{\mathrm{a}}$ & $5.17 \pm 0.06^{\mathrm{a}}$ \\
\hline
\end{tabular}

note: mean $\pm \mathrm{SD},{ }^{\mathrm{a}-\mathrm{f}}$ means within each column indicate significant differences $(p \leq 0.05)$ using Duncan's multiple range test.

\section{Effect of herbal supplement on the sensory acceptance of TJSC}

Herbal supplementation in TJSC was investigated (Table 6 and Figure 4). The herbs including ginger, galangal, lemongrass, sunchoke, and turmeric were compared with the control formula without herbs. Effect of herbal supplement on the appearance of TJSC was observed. It was found that TJSC with ginger, galangal, lemongrass, sunchoke, and control were light yellow in color. TJSC with turmeric was orange in color. The texture of all formulas was not different. Herbal formula had a unique aroma according to the type of herb. Sensory evaluation showed that the average score of appearance and texture in all formulas not different $(p>0.05)$. These had an average score of $7.20-7.63$ which moderate level. TJSC with turmeric had the lowest average score of flavors $(4.47 \pm 0.86)$, taste $(4.87 \pm 1.17)$, and overall liking $(4.83 \pm 1.09)$. It has a beautiful orange color, but most of the untrained panelists did not like the flavor of turmeric which is quite pungent. Herbs had specific fragrance that depends on personal preferences. For example, TJSC with ginger had a fragrance of ginger juice. 
http://wjst.wu.ac.th

Healthy TJSC consists of non-glutinous rice flour, corn milk instead of $50 \%$ coconut milk, and stevia leaf extract instead of $20 \%$ sugar was investigated chemical composition. The moisture content, protein, fat, carbohydrate, ash, and total energy of healthy TJSC were 9.75, 3.96, 7.91, 77.40, $0.98 \%$, and $408.35 \mathrm{kcal} / 100 \mathrm{~g}$. It was compared with the general formula (wheat flour, coconut milk and sugar). The moisture content, protein, fat, carbohydrate, ash, and total energy of the general formula were 9.89, 2.84, $12.35,74.31,0.61 \%$, and $432.45 \mathrm{kcal} / 100 \mathrm{~g}$. Interestingly, healthy TJSC had lower fat and total energy than TJSC in the general formula.

Table 6 The liking score $(n=30)$ of healthy TJSC from different herbs.

\begin{tabular}{llllll}
\hline \multirow{2}{*}{ Types of herbs } & \multicolumn{5}{c}{ Attribute } \\
\cline { 2 - 6 } & Appearance & Flavor & Texture & Taste & Overall liking \\
\hline Control & $7.67 \pm 0.71^{\text {ns }}$ & $7.53 \pm 0.82^{\mathrm{a}}$ & $7.50 \pm 0.51^{\mathrm{ns}}$ & $7.67 \pm 0.76^{\mathrm{a}}$ & $7.50 \pm 0.68^{\mathrm{a}}$ \\
Ginger & $7.63 \pm 0.67^{\mathrm{ns}}$ & $7.63 \pm 0.76^{\mathrm{a}}$ & $7.53 \pm 0.51^{\mathrm{ns}}$ & $7.80 \pm 0.61^{\mathrm{a}}$ & $7.63 \pm 0.67^{\mathrm{a}}$ \\
Galangal & $7.40 \pm 0.62^{\mathrm{ns}}$ & $7.50 \pm 0.68^{\mathrm{a}}$ & $7.50 \pm 0.68^{\mathrm{ns}}$ & $7.60 \pm 0.77^{\mathrm{a}}$ & $7.47 \pm 0.63^{\mathrm{a}}$ \\
Lemongrass & $7.43 \pm 0.68^{\mathrm{ns}}$ & $7.33 \pm 0.76^{\mathrm{ab}}$ & $7.47 \pm 0.57^{\mathrm{ns}}$ & $7.67 \pm 0.76^{\mathrm{a}}$ & $7.40 \pm 0.77^{\mathrm{a}}$ \\
Sunchoke & $7.33 \pm 1.35^{\text {ns }}$ & $7.00 \pm 0.79^{\mathrm{b}}$ & $7.23 \pm 0.82^{\mathrm{ns}}$ & $7.00 \pm 1.11^{\mathrm{b}}$ & $7.20 \pm 0.20^{\mathrm{b}}$ \\
Turmeric & $7.77 \pm 0.73^{\text {ns }}$ & $4.47 \pm 0.86^{\mathrm{c}}$ & $7.30 \pm 0.70^{\text {ns }}$ & $4.87 \pm 1.17^{\mathrm{c}}$ & $4.83 \pm 1.09^{\mathrm{b}}$ \\
\hline
\end{tabular}

note: mean $\pm \mathrm{SD}$, ${ }^{\mathrm{a}-\mathrm{c}}$ means within each column indicate significant differences $(p \leq 0.05)$ using Duncan's multiple range test and ns means not statistically significant $(p>0.05)$.

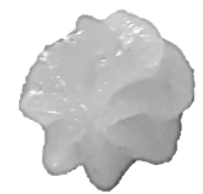

Control

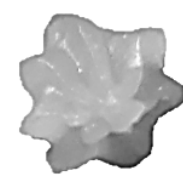

Ginger

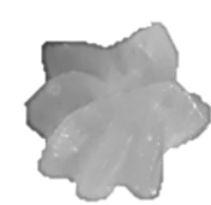

Galangal

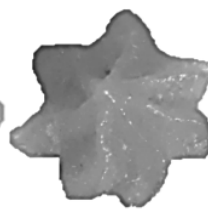

Lemongrass

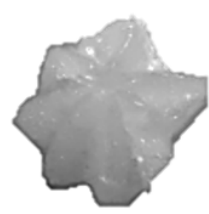

Sunchoke

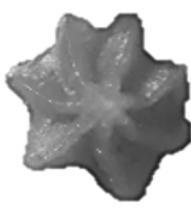

Turmeric

Figure 4 Appearance of healthy TJSC from various herbs.

\section{Conclusions}

The prototype of healthy TJSC consisted of $10 \mathrm{~g}$ non-glutinous rice flour, $30 \mathrm{~g}$ coconut milk, $30 \mathrm{~g}$ corn milk, $24 \mathrm{~g}$ sugar, $6 \mathrm{~g}$ stevia leaf extract, and $0.5 \mathrm{~g}$ herb powder such as ginger, galangal, lemongrass, and sunchoke. Healthy TJSC was high nutrition. It is an alternative food for consumers who there are restrictions on eating, and want to avoid certain ingredients in the food such as gluten, or want to avoid high fat and sugar content in food, etc. In addition, consumer groups like to eat herbs. The knowledge gained from this research can be used as a guideline for healthy food product development that it can be extended to commercial production. Further studies may be conducted regarding proper packaging and shelf life of products.

\section{Acknowledgements}

The author would like to warmly thank the community enterprise of the herbs in Sa Kaeo province, which supported raw materials and information for this study.

\section{References}

[1] N Srisangwan. Nutritional improvement of a-lua and foi-thong desserts by using nonsugar sweeteners. Master's Thesis, Silpakorn University, Bangkok, 2012. p. 1-171

[2] N Charoenphun. Production of "look choub" cake from broken thai jasmine rice flour. Thai Sci. Technol. J. 2019; 27, 915-23. 
http://wjst.wu.ac.th

[3] T Chakrabarti, A Poonia and AK Chauhan. Process optimization of gluten free cookies using cassava flour. Inter. J. Food Sci. Nutr. 2017; 2, 190-5.

[4] M Rostamian, JM Milani and G Maleki. Physical properties of gluten-free bread made of corn and chickpea flour. Inter. J. Food Eng. 2014; 10, 467-72.

[5] N Charoenphun. Development of cookie products from sweet potato. J. Food Tech. Siam Univ. 2018; 13, 32-43.

[6] N Chalermnon, W Khantachai and P Samakkan. Quality of virgin coconut oil produced by a centrifugal method. Research Report, Rajamangala University of Technology Suvarnabhumi, Phra Nakhon Si Ayutthaya, 2016. p. 1-24.

[7] N Charoenphun, J Kiawvijit and S Deeharing. Development of kanomtuay product for health. $J$. Food Tech. Siam Univ. 2018; 13, 24-35.

[8] K Chaweewan. Substitution of coconut milk with purple corn milk in arlua. Senior Project, Rajamangala University of Technology Krungthep, Bangkok. 2017. p. 1-56.

[9] P Watanachai, S Manakla, T Kongyen, P Bangkhan and S Jitsophakul. The use of milk and powdered milk instead of coconut milk in ice pink milk custard bread product. The $2^{\text {nd }}$ Kamphaeng Phet Rajabhat University National Conference, Kamphaeng Phet, Thailand. 2015, p. 620-6.

[10] W Tapyotin, N Senawong and J Muangphon. The quality and consumer acceptance of corn milk powder with sugar coating and pasteurized process. RMUTP Res. J. 2014; SI, 192-202.

[11] P Kulkanjanatorn. Stevia, Available at: https://www.pharmacy.mahidol.ac.th/knowledge/files/ 0221.pdf, accessed March 2020.

[12] S Inchuen, T Naratippakorn and S Khewruang. Effect of holy basil leaf powder on wheat flour property and cookies quality. Khon Kaen Agr. J. 2018; 46, 1387-94.

[13] Association of Official Analytical Chemists (AOAC International). Official methods of analysis. $19^{\text {th }}$ ed. Washington DC, 2012.

[14] DB Duncan. Multiple range and multiple F tests. Biometrics 1995; 11, 1-42.

[15] N Rattanapanone. Food chemistry. Bangkok, Odian Store, 2014, p. 1-504.

[16] P Pornchaloempong and N Rattanapanone. Evaporation, Available at: http://www.foodnetworksolution.com, accessed March 2020.

[17] K Sriroth and K Piyachomkwan. Starch technology. Kasetsart University Press, Bangkok, Thailand, 2007, p. 1-303.

[18] R Caprita and A Caprita. The variation of relative and reduced viscosity with concentration in wheat and barley aqueous extracts. Animal. Sci. Biotech. 2012; 45, 117-120.

[19] T Kaewnoo and H Phonrak. Sugar science. J. Sugar. 2017; 1, 33-51.

[20] P Wetwitayaklung. Coconut proteins. Thai Bull. Pharm. Sci. 2013; 8, 9-18.

[21] J Bunyasawat and C Bhoosem. Effect of substitution durian powder with wheat flour on tarts quality. RMUTP Res. J. 2017; 11, 48-58.

[22] Department of Science Service, Anthocyanin, Available at: http://siweb.dss.go.th/repack/fulltext/ IR21.pdf, accessed March 2020.

[23] P Simantara, A Auvuchanon, D Ampoln and P Kloyswat. Changes of colour and beta-carotene contents in cooked pumpkins. Khon Kaen Agr. J. 2014; 42, 870-5.

[24] S Ariyaprakai. Coconut milk emulsions. KMUTT Res. Dev. J. 2014; 37, 89-95.

[25] A Chieovej. Study on the use stevia to replace some sugar in gub dessert product. Master's Thesis, Rajamangala University of Technology Phra Nakhon, Bangkok, Thailand, 2018. p.1-93.

[26] S Suwannarong, P Chotthanom, K Banlue, B Niyom and K Kanarun. Comparison of stevia leaf extract (Stevia rebaudiana) and sucrose sugar addition on the textural properties of Kanomtian crust. Khon Kaen Agr. J. 2019; 47, 657-62. 